\title{
Teachers' Perception of the Effectiveness of Methods of Teaching Social Studies in Ekiti State, Nigeria
}

\author{
Bilqees Olayinka Abdu-Raheem ${ }^{1, *}$ \\ ${ }^{1}$ Department of Educational Foundations and Management, Faculty of Education, Ekiti State University, Ado-Ekiti, \\ Nigeria \\ *Correspondence: Department of Educational Foundations and Management, Faculty of Education, Ekiti State \\ University, Ado-Ekiti, Nigeria. Tel: 234-806-089-4068 E-mail: dr_boabduraheem@yahoo.com
}

Received: January 17, 2015

Accepted: March 1, 2015 Online Published: March 27, 2015

doi:10.5430/wje.v5n2p33

URL: http://dx.doi.org/10.5430/wje.v5n2p33

\begin{abstract}
This study sampled the perception of secondary school teachers on the effectiveness of various methods used to teach Social Studies in secondary schools. It also examined the methods that facilitate learning more, the method commonly used by male and female teachers and also by qualified and non-qualified teachers. The population consisted of all secondary school teachers in Ekiti State and the sample comprises of 320 teachers who responded to a questionnaire designed by the researcher to express their opinion on the subject matter. Simple random sampling was used to select ten teachers from each school sampled. The validity of the instrument was ensured by experts in Social Studies and Educational Management.The reliability of the instrument was ascertained through test-re-test method and the reliability coefficient of 0.81 was obtained.One research question was raised and three hypotheses formulated were tested at 0.05 level of significance. The data collected were analysed using Kendall' Rank Order Correlation and t-test statistical tools. The study revealed that teachers perceived problem-solving as the best method and note-dictation as the least effective method of teaching Social Studies. It was discovered that teachers are significantly related in their perception of the effectiveness of methods of teaching Social Studies. It also showedthat male and female teachers are related in the methods used but the methods used by qualified teachers are different from those used by non-qualified teachers. It was therefore recommended that more qualified teachers should be employed to improve the quality of teaching in schools.
\end{abstract}

Keywords: effectiveness; teaching methods; facilitating; learning; teachers' perception; social studies

\section{Introduction}

Social Studies is a realistic subject that studies human beings in the real life situation. One salient fact derived from the study of Social Studies is the recognition of human being as the most important aspect of learning and development of purposeful skills and knowledge to enable them function well in the society.It is essential for teachers to use child- centred methods to realise the stated objectives, goals and aims of the subject. Abdu-Raheem (2011) observed that the objective of Social Studies is yet to be achieved as a result of poor teaching and lack or inadequacy of instructional materials to motivate students.

The effectiveness of the various methods of teaching Social Studies in secondary schools has been a matter of grave concern to the stakeholders in education over the last two decades. This is because secondary school has been described as the determinant of the success and failure of the whole education system. Based on the philosophy of education in Nigeria, the ultimate aim of secondary school education is to transform the individual into a sound and effective citizen (Federal Republic of Nigeria, 2004).

In his own study, Oni in Abdu-Raheem (2010) pointed out that instructional format provided by the teacher seems to be the medium of effective learning and that good teaching makes learning more meaningful. He went further to affirm that while good teaching helps the learner to learn more quantitatively and qualitatively, poor teaching would lead to poor learning and hence poor performance. In support of this statement, Cresswell (2004) asserted that effective teachers present information or skills clearly and enthusiastically, are non-judgmental and relaxed, keep the lessons task-oriented, aim at students' achievement, interact with students through probing questions and assist students by elaborating their answers. 
In addition, Adewuya (2003) saw brainstorming in discussion method as a way of clarifying certain ideas and explore contributions and feelings of intellectually-charged minds to the maximum limit. Stephen and Stephen (2005) stated that discussion method is a process of giving and talking, speaking and listening, describing and witnessing which helps expand horizons and foster mutual understanding. Abdu-Raheem (2011) explained that discussion method of teaching engages both teachers and students in thinking and develops in students social skills of talking and listening. Yusuf and Al-Banawi (2013) also added that involving students in class activities and discussion engages them and promotes their desire to learn the subject.

Again, Kupolati in Abdu-Raheem (2010) suggested inquiry, problem-solving, discussion, discovery and role playing as effective methods. Yewande (2000) and Adewuya (2002) believed that problem-solving is using information and reasoning to overcome obstacle barrier. Abdu-Raheem (2012) also agreed that problem-solving method is effective because students are able to participate actively in the lessons. Richards (2005) and Ogunkunle (2008) also agreed that self-directed learning makes learning effective and meaningful to learners, improve and develop problem-solving abilities in learners and also take care of all categories of learners.

Indeed, according to Sumber, Ndofirepi and Gwirayi (2012), the teaching style of the teacher should match the learning style of the learners in order for learners to understand what the teacher is teaching. They posited that learners should be at the forefront or in the driver's seat and in charge of their own learning while the teacher acts as a facilitator during teaching- learning process. Adesanya and Adesina (2014) noted that meaningful teaching and pleasant learning of basic concepts and processes can only be accomplished within the instructional framework with the combination of teaching strategies and approaches.

Lecture method allows a great deal of information to be passed to the learner and favours handling of large classes. In spite of the advantages, Seweje (2000), Adewuya (2002) and Abdu-Raheem (2012) lamented that the method does not stimulate students' innovations, inquiry and scientific method.It encourages students to cram facts that are easily forgotten (Okwilagwe,2000) Extensive use of the method tends to substitute the teacher for the student (Kochhar, 2012) It leads to students' fading memories and decreases students' attention (Jekayinfa 2012).Adesanya and Adesina (2014) also asserted that teaching and learning is famous of conventional teaching where teacher is the centre of the teaching, a controller of the class activities and a dictator while the learner is a passive learner who takes all the words of the teacher without interaction between him and the teacher.

In the same vein, Adelekan in Afolabi, Abidoye and Afolabi (2013) lamented that in spite of the laudable objectives and benefits of social studies in the school curriculum, the teaching of the subject is characterized by conventional method of teaching which always lead to ineffective learning and poor attitude of students towards the subject. Oluwagbohunmi and Abdu-Raheem (2014) stressed that old methods of teaching must be discarded and new ones that are activity based and ensure active involvement of learners must be employed to ensure achievement of learning objectives.

However, Afolabi (2000) stressed the need for a continuous systematic programme of professional improvement to enhance the effectiveness and efficiency of teaching. Sotonwa (2003) agreed that good teaching matters in raising the standard of education and achievement of students .Bandele (2003) believed that the health of classroom interaction is dictated by the quality of instructions given during the actual lesson periods. The reason being that teacher holds the key to nation-building (Musa 2004).Bandele (2006) further alerted that educational evaluation can be considered in terms of classroom teaching, curriculum, social action or educational programmes

Teachers are so important that Sofoluwe (2003) referred to them as the pivot on which qualitative education and development hangs. As a result, teachers should be fully devoted to continuous self-improvement for concerted promotion of education (Obanya 2003). Okandeji (2007) also observed that among the yardsticks of quality in any given educational venture are the qualification and experiences of its teachers. Sotonwa (2003) suggested that discussion on some aspects of classroom teaching should be held with the teachers during inspection. Owolabi (2003) submitted that a teacher as an instructor is responsible to teach, direct, control, interpret and instruct the learners for better attainment. Fatoba (2008) affirmed that teachers have crucial roles to play in the delivery as well as the quality of education given to students in Secondary Schools.

Teachers need to be well equipped in the methods of teaching as the teacher is responsible for translating policy into action in the classroom.However, effective and efficient Social Studies teachers must have the knowledge of what to teach and how to teach it. They must have the knowledge of the content and master the teaching methods and strategies to facilitate effective interaction between the learners and the content. They should also give room for students' own process of the exploration and discovery which is otherwise known as problem-solving method of teaching. Ayodele (2007) alerted that the objectives of the lesson will prompt the teacher to select the appropriate 
method.

According to Bandele (2003), the effectiveness of this approach depends largely on the proper orientation of teachers towards the use of the method, the characteristics of the learners and the nature of the content. Eggen and Kauchak (2001) declared that where pedagogical content knowledge is lacking, "teachers commonly paraphrase information in learner's textbooks or provide abstract explanations that are not meaningful to their students". Adediwura, Bada, Ajeigbe \& Bamidele (2008) asserted that teachers' variables such as teachers' knowledge of subject matter, teaching skills, attitude in the classroom, teacher's qualification and teaching experience are noted to have effects on students' academic performance.

National Policy on education (FGN, 2004) stated that no education system can arise above the quality of its teacher and this implies that teachers should be properly trained to achieve excellence. Ajayi (2007) acknowledged the fact that teacher is the hub of any educational system. He stressed that the educational system rotates round the teacher as the wheel rotates round the hub. Osokoya (2008) put into record that 1969 National Conference described teachers as the key man in the entire educational programme. Paulley (2013) suggested that teachers' education programmes should be structured to equip teachers for the performance of their duties.

Furthermore, Irvine (2001), defined caring teachers as those who set limits, provide structures, hold high expectations and push them to achieve. Omotayo (2001) submitted that teachers must be master of their craft to be significantly effective. Nwangwu (2005) confirmed that it is not possible to have quality education without having quality and competent teachers. Ngada (2006) emphasized that no adequate training of any sort can take place without recruiting qualified teachers to handle programmes of study.

In her own view, Omotayo (2007) also concluded that the crucial roles the teacher plays in every teaching-learning situation cannot be over- emphasized. However, some of theroles teachersplay are as follows: Teachers assist to develop the capacities of learners intelligently on how to solve problems of survival. They serve as role models for students by setting limits andprovide framework or essential parts towards success in life. They understand the needs and aspirations of students and always work towards the achievement of their aims and objectives. They are the key motivators of students and major predictors of quality of education in the country. They are also the builders of the nation by imparting knowledge needed to become professionals in all areas such as medicine, law, engineering, agriculture, social sciences, management sciences and political sciences.

\section{Statement of the Problem}

It was observed that many students do not pass well in the Junior Secondary School Certificate Examinations in Social Studies. Among the factors responsible for the students' poor academic performance in the subject is the inappropriate teaching methods adopted by the teachers (Adewuya, 2003; Abdu-Raheem 2010). By implication, the effective method of teaching Social Studies has not been identified.

\section{Purpose of the Study}

The purpose of this study is to find out the perception of the teachers on the effectiveness of the various methods of teaching Social Studies so as to identify and recommend the best methods that can facilitate learning and improve the academic performance of Junior Secondary School students in their internal and external examinations.

\section{Research Question}

1. What is the perception of teachers on the effectiveness of various methods of teaching Social Studies?

\section{Research Hypotheses}

1 There is no significant relationship in the perception of secondary school teachers on the effectiveness of methods of teaching used to teach Social Studies.

2. There is no significant difference between the perception of teachers on methods of teaching used by male and female teachers to teachSocial Studies in secondary schools

3. There is no significant difference between the perception of teachers on methods of teachingused to teach Social Studies by qualified and non-qualified teachers in secondary schools. 


\section{Methodology}

Descriptive research design of the survey type was adopted for the study. The instrument used for collecting data was a self-designed questionnaire which sough information on perception of teachers on various methods used to teach Social Studies, the methods used by male and female teachers and qualified and non-qualified teachers. The instrument was validated by experts in Educational Management and Social Studies to assess the suitability or otherwise of the items in the instrument. The face and content validities were ensured by the experts. The reliability of the instrument was ascertained through test-re-test method. The instrument was first administered on 30 students that were not used for the study, after 6weeks the instrument was re-administered on the same set of students. The scores of the two sets were correlated using Pearson Product Moment Correlation Coefficient Analysis. The correlation coefficient of 0.81 was obtained. This is an indication that the instrument is reliable. The instrument was administered on 320 teachers that were selected from 32 secondary schools in Ekiti State. Simple random sampling was used for the selection. The data were analysed using Kendall's Rank Order Correlation and t-test statistical tools. The teachers who specialised on Social Studies with First Degree and above were regarded as qualified in this study. Non-qualified were those with National Certificate in Education (NCE) and First Degree in other subjects. One research question was raised. Three hypotheses generated were tested at 0.05 level of significance.

\section{Results and Discussion}

\subsection{Research Question}

What is theperception of teachers on the effectiveness of various methods of teaching social studies?

Table 1. Kendall's W. Rank Order of Teachers' Perception of Various Methods of Teaching Social Studies

\begin{tabular}{lllllll}
\hline S/N & METHODS & $\mathbf{R}$ & $\mathbf{R}^{\mathbf{2}}$ & $\mathbf{R A N K}$ & $\mathbf{W}(\mathbf{N}-\mathbf{1}) \mathbf{K}$ & $\mathbf{W t}$ \\
\hline 1 & Problem solving & 1015 & 1030225 & $1^{\text {st }}$ & & \\
2 & InquirylDiscovery & 1068 & 1140624 & $2^{\text {nd }}$ & \\
3 & Discussion & 1189 & 1413721 & $3^{\text {rd }}$ & \\
4 & Question\Answer & 1235 & 1525225 & $4^{\text {th }}$ & \\
5 & Role play & 1315 & 1729225 & $5^{\text {th }}$ & \\
6 & Excursion & 1535 & 2356225 & $6^{\text {th }}$ & \\
7 & Project & 1643 & 2699449 & $7^{\text {th }}$ & \\
8 & Computer Assisted & 1672 & 2795585 & $8^{\text {th }}$ & & \\
9 & Creative Activity & 1687 & 2845969 & $9^{\text {th }}$ & & \\
10 & Lecture & 1791 & 3207681 & $10^{\text {th }}$ & 278.72 & 22.36 \\
11 & Simulation & 1836 & 3370896 & $11^{\text {th }}$ & & \\
12 & Observation & 1868 & 3489424 & $12^{\text {th }}$ & & \\
13 & Construction & 1912 & 3655744 & $13^{\text {th }}$ & & \\
14 & Note-Dictation & 2131 & 4541161 & $14^{\text {th }}$ & & \\
$\mathrm{P}<0.05, \mathrm{k}=320, \mathrm{n}=14, \mathrm{~W}=0.067$ & & & &
\end{tabular}

Table 1 presents the ranking of teaching methods effectiveness as perceived by Social Studies teachers. The results show that Problem Solving is ranked as the most effective teaching method with the least $\mathrm{R}$ value (1015). This is closely followed by Inquiry $\backslash$ Discovery $(R=1068)$, Discussion $(R=1189)$, Question\& Answer $(R=1235)$, Role Play $(\mathrm{R}=1315)$, Excursion $(\mathrm{R}=1535)$, Project $(\mathrm{R}=1643)$, Computer Assisted $(\mathrm{R}=1672)$, Creative Activity $(\mathrm{R}=1687)$, Lecture $(\mathrm{R}=1791)$, Simulation $(\mathrm{R}=1836)$, Observation $(\mathrm{R}=1868)$, Construction $(\mathrm{R}=1912)$, while Note-Dictation method, with the $\mathrm{R}$ value (2131), is ranked the least effective strategy for teaching Social Studies in secondary schools.

\subsection{Hypotheses 1}

There is no significant relationship in perception of teachers on effectiveness of various methods of teaching Social Studies in secondary schools.

From the result in table 1 above, the null hypothesis is not accepted. $(\mathrm{Wc}=278.72, \mathrm{Wt}=22.36, \mathrm{p}<0.05)$. Therefore, there is significant relationship in the perception of teachers on effectiveness of various methods of teaching Social Studies in schools. It implies that Social Studies teachers are significantly related in their perception on effectiveness of various methods of teaching Social Studies. 


\subsection{Hypothesis 2}

There is no significant difference between the perception of teacherson the methods used by male and female teachers to teach Social Studies in secondary schools.

Table 2. t-test Showing the Teaching Methods of Social Studies Teachers by Gender

\begin{tabular}{lcccccc}
\hline \multicolumn{1}{c}{ Group } & $\mathrm{N}$ & Mean & SD & Df & t-cal & t-table \\
\hline Male & 128 & 47.20 & 5.17 & & & \\
Female & 192 & 48.20 & 6.08 & 318 & 1.533 & 1.960 \\
\hline
\end{tabular}

$\mathrm{p}>0.05$

Table 2 shows that t-cal (1.533) is less than t-table (1.960) at 0.05 level of significance. The null hypothesis is accepted. This implies that there is no significant difference between the methods used by male and female teachers to teach Social Studies. The result in this table shows that the main effect of gender on methods of teaching social studies by teachers is not significant. The teaching methods used by male and female teachers of the same level of education are related.

\subsection{Hypothesis 3}

There is no significant difference between the perception of teacherson the methods of teaching Social Studies by qualified and non-qualified teachers.

Table 3. t-test Showing the Methods of Teaching Social Studies by Qualified and Non-Qualified Teachers

\begin{tabular}{ccccccc}
\hline Group & $\mathrm{N}$ & Mean & SD & Df & t-cal & t-table \\
\hline Qualified & 93 & 48.62 & 6.20 & & & \\
Non-Qualified & 227 & 45.37 & 5.17 & 318 & 4.808 & 1.980 \\
\hline
\end{tabular}

$\mathrm{P}<0.05$

Table 3 shows that $t$-cal (4.808) is greater than t-table (1.980) at 0.05 level of significance. The null hypothesis is not accepted. This implies that there is significant difference in the methods of teaching Social Studies by qualified and non-qualified teachers. This is an indication that qualified teachers can teach the subject better than non-qualified teachers because they are experts in the field and they can use their expertise to improve and predict the quality of teaching in the classroom.

\section{Discussion}

This study found out that teacher perceived problem-solving as the best method to be used in facilitating learning in Social Studies. This is in line with Orimogunje (2008) who emphasized the need for using an innovative strategy such as problem-solving to correct the mismatch of post-primary Social Studies with the traditional lecture method.

It was also revealed in the study that there is no significant difference in the method used by male and female teachers. Abdu-Raheem (2012) agreed that gender does not play any significant role in Social Studies.

The study also discovered that there is significant difference in the methods used by qualified and non-qualified teachers.This submission is in agreement with Ayodele (2007) who emphasized that teacher's methodology is very important in the sense that it may hinder learning, initiative and curiosity.

\section{Conclusion}

It was concluded in this study that teachers perceived problem-solving as the best method andnote-dictation as the last. It was also noted that there is significant difference in the methods used by qualified and non-qualified teachers. This is an indication that only qualified teachers can teach Social studies effectively to achieve the objectives of the subject. The study also concluded thatgender does not play any significant role in Social Studies as the methods used by male and female teachers of the same qualifications are related.

\section{Recommendations}

1. It was therefore recommended that teachers of Social Studies should use innovative methods such as problem-solving, discovery, discussion, questions and answers, role play, excursion and computer assistedfor the 
improvement of students' academic performance in schools.

2. Principals should provide Social Studies teachers with enabling environment for the use of various methods that can enhance learning and also gives room for participatory studentship.

3. Government should employ more qualified teachers to enhance the quality of teaching in secondary schools.

4. Government should organize on-the-job training, seminars, workshops, symposia and conferences at intervals for Social Studies teachers in secondary schools to update their knowledge on methods of teaching that can allow students to be at the centre of learning and also improve their academic performance.

5. Government should also give teachers' welfare a priority by giving them remuneration and encouragement both in cash and kind.

\section{References}

Abdu-Raheem, B.O. (2010). Relative effects of problem-solving and discussion methods on Secondary school students' achievement in Social Studies. Unpublished Ph. D. thesis, University of Ado-Ekiti, Ado-Ekiti, Nigeria.

Abdu-Raheem, B.O. (2011). Effects of discussion method on secondary school students' achievement and retention in Social Studies. European Journal of Educational Studies, 3(2), 293-301.

Abdu-Raheem, B.O. (2012). Effects of problem-solving method on secondary school students' achievement and retention in Social Studies in Ekiti State, Nigeria. Journal of International Education Research, 8(1), 19-25.

Abdu-Raheem, B.O. (2012). Gender differences and students' academic achievement and retention in Social Studies among junior secondary schools in Ekiti State. European Journal of Educational Studies, 4(1), 155-161.

Adediwura, A.A., Bada, T.A., Ajeigbe, T.O., \& Bamdele, F.I. (2008). Students perception of teacher's characteristics as predictor of academic performance n Nigerian secondary schools. Journal of Educational Foundations and Management, 6(1), 45-58.

Adesanya, A.O., \& Adesina, O.J. (2014). Self-directed learning strategy in teaching and learning for development in the third world. International Journal of Special and General Education, 3, 60-65.

Adewuya, S. A. (2002). Principles and concept of Social Studies. Ado-Ekiti: Yemi Publishing Co. Ltd.

Adewuya, S.A. (2003). Social science methods. Ado-Ekiti: Green Line Publishers.

Afolabi, A. K, Abidoye, J.A., \& Afolabi, A.F. (2013). Effects of instructional media on the academic achievement of students in social studies in junior secondary schools.PNLA quarterly. Retrieved 09/11/14 from Unllib.uni.edu/LPP/PNLA\%2520Quater

Afolabi, F. O. (2000). Preparation of teachers for the effective implementation of secondary school curriculum in Ondo State. Journal of Educational Research and Evaluation, 4(1), 1-8.

Ajayi, K. (2007). Emergent issues in teacher education and professionization of teaching in Nigeria. African Journal of Historical Sciences in Education, 3(1), 5-25.

Ayodele, C.A. (2007). Relative effect of demonstration and video tape mediated instructional strategies on secondary school students' performance in Yoruba language. Unpublished B.A. (Ed.) Project, University of Ilorin, Ilorin.

Bandele, S. O. (2003). The universal basic education in perspective need for formative evaluation. Nigerian Journal of Educational Research and Evaluation, 4(1), 54-58.

Bandele, S.O. (2006). Test measurement and evaluation: The educational tripod, $17^{\text {th }}$ Inaugural Lecture, University of Ado-Ekiti, Nigeria.

Cresswell, J. (2004). Schooling issues digest: school effectiveness. Retrieved from http://dest.gov.au./publications/2004/index.htm

Eggen, P., \& Kauchak, D. (2001). Educational psychology: Windows on classrooms. New Jersey Prentice Hall, Inc.

Fatoba, J.O. (2008). Teacher competency in handling integrated science in the junior secondary schools in Ekiti State. Journal of Educational Foundations and Management, 6(1), 222-227.

Federal Republic of Nigeria (2004). National policy on education $\left(4^{\text {th }} \mathrm{ed}\right)$. Nigeria NERDC Press.

Irvine, J.J. (2001). Caring, competent teachers in complex classrooms. Washington D.C. AACTE Publications.

Jekayinfa, A.A. (2012). Fundamentals of instructional methods. Ilorin, Olives Productions Ltd. 
Kochhar, S.K. (2012). The teaching of social studies. New Delhi, India.Sterling Publishers Private Limited.

Musa, H.B. (2004). Preface to teachers' code of conduct. Kaduna: Teachers' Registration Council of Nigeria

Ngada, (2006). Teacher quality: Implication for the implementation of certain curriculum contents of some selected metropolitan secondary schools of Borno State. Journal of Educational Studies, 9(1), 106-114.

Nwangwu, I.O. (2005). Quality assurance in public secondary schools: issues and concerns. Nigerian Journal of Educational Administration and Planning, 5(1), 229-234.

Obanya, P. A. I. (2003). Quality evaluation of basic education: A comprehensive model. Nigerian Journal of Educational Research and Evaluation, 4(1), 87-89.

Ogundipe, B.D. (2003). Evaluation of inputs of primary education programme in Oyo State. Nigerian Journal of Educational Research and Evaluation, 1(4), 19-24.

Ogunkunle, O.J. (2008). Towards enhancing self-learning in teaching creative arts in our secondary schools.Art Monitor, A Journal of the Department of Creative Arts, Tai Solarin University, Ijebu-Ode, Ogun State. 1, 120-128.

Okandeji, C.O. (2007). Quality assurance in higher education. In J.B. Babalola, G.O. Akpa, A.O. Ayeni and S.O. Adedeji (eds.), Access, Equity and Quality in Higher Education. NAEAP Publications.

Okwilagwe, E.A. (2003). Quality assurance of teaching and learning process of the UBE primary education through effective monitoring and education. Nigerian Journal of Educational Research and Evaluation, 4(1), 79-86.

Oluwaghohunmi, M.F., \& Abdu-Raheem, B.O. (2014). Sandwich undergraduates' problem of improvisation of instructional materials in social studies: The case of Ekiti State University. Journal of International Academic Research for Multidisciplinary, 1(12), 824-831.

Omotayo, K.A. (2001). Qualitative science teacher preparation to meet the challenges of science and technological development. Journal of Issues in Technical Teacher Education, 2(1), 90-95.

Omotayo, K.A. (2007). Teacher quality: An imperative for achieving a worthwhile UBE in Nigeria. Journal of Educational Foundations and Management, 5(1), 85-91.

Osokoya, I.O. (2008). Contemporary issues in educational history and policy in Nigeria. Ibadan: Laurel Educational Publishers Ltd.

Owolabi, O.T. (2003). Effect of error correcting instructional packages on prevalent errors in physics practical in Nigerian secondary schools. Unpublished Ph.D Thesis.Unversity of Ado-Ekiti, Nigeria.

Paulley, F.G. (2013). The policy and practice of preparing the Nigerian teachers for the challenges of the new generation: The National Policy on Education in Focus. A Paper Presented at the $10^{\text {th }}$ Annual National Conference of the History of Education at Federal College of Education, Okene, Kogi State, Nigeria. December, $2-6$.

Rechards, L.J. (2005). Development a decision model to describe levels of self-directed based upon the key assumptions of andragogy. M. Ed Thesis. TaxasA\& M University Retrived from //:handle.tamu.edu/1996.1/2685

Seweje, R.O. (2000). The challenges of science teaching in Nigeria today. Journal of Educational Foundations and Management, 1(1), 208-222.

Shumba, A. Ndofirepi, A. P., \& Gwirayi, P. (2012). A critique of contructivist theory in science teaching and learning. International Journal of Social Sciences, 31(1), 11-18.

Sofoluwe, A. O. (2003). Evaluation of the total quality management of primary education in Nigeria. Nigerian Journal of Education Research and Evaluation, 4(1), 25-33.

Sotonwa, O.O. (2003). Quality teacher and quality teaching towards achieving quality in Universal Basic Education. Nigerian Journal of Educational Research and Evaluation, 4(1), 69-78.

Stephen, D., \& Stephen, P. (2005). Discussion as a way of teaching.United State of America.Jossey Bass Press. A Willey Imprint. Retrieved from www.josseybass.com

Yewande, (2000). The effect of problem-solving techniques on students' achievement in senior secondary Chemistry. M. Ed. Project, University of Ibadan, Ibadan.

Yusuf, N., \& Ai-Banawi, N. (2013). The impact of changing technology: The Case of E-Learning. International Journal of Contemporary Issues in Education, 6(2), 173-180. 